\title{
Translation for and in Performance: Fusion of Horizons of Hebrew psalmist and Zulu Translator- Performer in the Zulu "Performance Arena"
}

\author{
JUNE F. DiCKIE (UNIVERSiTy OF KWAZULU-NATAL)
}

ABSTRACT

This empirical study explores whether indigenous Zulu praise-poetry can inform the translation of biblical praise-psalms. Zulu youth ("poetry fans") were invited to learn about Hebrew and Zulu poetics as well as the process of Bible translation. Then they made their own translations and performances of biblical praise-psalms, following the Literary-rhetorical approach of Ernst Wendland.

The results show a strong Zulu imprint from the source to the receptor text, although the original message is retained along with some of the poetic features. The literary and rhetorical power of the Hebrew is transformed into images and thought patterns that come alive to the Zulu mind while still being acceptable (to them) in terms of biblical accuracy. The performances of the translated texts (using rap, song, or spoken poetry) utilise prosody to deliver the message, thus requiring some adjustment to the texts. The audience enters into the experience, impacting the performers. Thus, there are four "voices" apparent: those of the original author, the Zulu translator, the Zulu performer, and the audience. A rich texture of cultural beauty emerges as the Hebrew and Zulu horizons merge in a panorama of literary beauty and rhetorical power.

KEYWORDS: Bible translation, psalms, community, oral performance

\section{A INTRODUCTION}

In Africa, ${ }^{1}$ praise-poems are traditionally performed at ceremonies to celebrate the feats achieved by a famous person. ${ }^{2}$ The focus is less to praise the person than to praise the positive characteristics (and criticise, in a veiled way, the negative characteristics) with the goal of reinforcing acceptable behaviour in

* Submitted: 12/01/2018; peer-reviewed: 02/05/2018; accepted: 03/05/2018. June Dickie, "Translation for and in Performance: Fusion of horizons of Hebrew psalmist and Zulu translator-performer in the Zulu 'performance arena,"' OTE 31 no. 2 (2018): 399-422. DOI: https://doi.org/10.17159/2312-3621/2018/v31n2a8.

1 Praise-poetry is used across Africa, but for this article, the focus is on Zulu poetry. However, much of what is said relates equally to other African languages.

2 See A. Trevor Cope, Izibongo Zulu Praise Poems (London: Oxford University Press, 1968). 
society. Nevertheless, the fact that the Zulu community has a long history of such praise poetry, and that young people today are passionate about composing and performing poetry, provides a significant opportunity to utilise this form of indigenous poetry in the translation of some biblical praise psalms. To test this hypothesis in my doctoral work, I undertook an empirical study in which volunteers were invited to receive basic training in principles of Bible translation and Hebrew / Zulu poetic devices. Thereafter, they made their own translations of three praise-psalms (one on each of three days of "workshop"), and then performed their translations (or portions thereof) before an audience of their peers or the church congregation. ${ }^{3}$

The theoretical basis for the study was the literary-rhetorical method of analysing biblical poetry developed by Ernst Wendland (2006). This involves following twelve steps to analyse the Hebrew poetry to determine the literary and rhetorical devices used in the source text, and the functions achieved by these. For example, the use of repetition might provide rhythm and serve a mnemonic function; the use of chiasm might act as a memory device and also highlight the main point; and the use of inclusion might indicate topicboundaries. $^{4}$

Before undertaking the workshops with the Zulu participants, I analysed three Hebrew praise-psalms using Wendland's methodology. The poetic features in the Hebrew text were discussed with the participants, along with a review of poetic features in Zulu. The Zulu "poets" were encouraged to use poetic devices in Zulu that performed the same function as those in the Hebrew. They then made their translations. The results yielded rich data, indicating the "presence" in the translated poems of, first, the original Hebrew author, and second, the Zulu translator. Wendland's theoretical approach formed the basis for identifying these first two voices, or "presences".

The poets then transformed their compositions into performances. This required them to make further adjustments in order to fit the performance "arena". 5 Notions of performance criticism that had to be considered included paralinguistic features (such as the intonation pattern, rhythm, speed and volume of delivery) as well as extra-linguistics features (such as gestures, facial expressions and clothing). All these performance elements are part of the message that is delivered, and thus constitute the third "presence", namely that

3 Four workshops were held with four different church/poetry groups, each studying the same three praise-psalms.

4 For more discussion of the Literary-rhetorical method and functional equivalence in translation, see June F. Dickie, "Zulu Song, Oral Art, Performing the Psalms to Stir the Heart" (Ph.D thesis, UKZN), 2017: section 2.6.

${ }^{5}$ Foley uses the term "arena" to refer to the physical context of a performance (John M. Foley, The singer of tales in performance [Bloomington: Indiana University Press, 1995]). 
Dickie, "Translation for and in Performance," OTE 31/2 (2018): 399-422

of the performer. Performance criticism also refers to the central role played by the audience in influencing the performance. Thus, when the Zulu youth performed their poems before their peers or the church congregation, the fourth "presence", namely that of the audience, was also apparent.

The idea of four "presences" in the performed translation can be delineated by observing the two "presences" (those of original author and translator) arising from an application of Wendland's Literary-rhetorical method, and two "presences" (those of the performer and audience) arising from an application of Performance criticism. This paper considers these four different "presences" in the light of various Zulu examples.

\section{B PRESENCE OF THE "ORIGINAL AUTHOR"}

Before the translators made their own compositions, they studied an EnglishHebrew interlinear text as well as various translations in English and the current (1959) Zulu translation. From my analysis of the Hebrew text (using Wendland's literary-rhetorical approach), I was able to communicate to the participants the poetic features of the text, and we discussed the functions achieved by such devices. The participants also learned to pick up repetitions of Hebrew words (from the English interlinear). To help them recognise structures such as parallelism, inclusio, and chiasm in the Hebrew text, we looked together at fairly literal translations in English (e.g. ESV) and the Zulu text. More free translations (such as the NLT or TEV) assisted with understanding key terms.

Zulu praise-poems were also studied to determine which poetic devices are traditionally used in such poems. Many similarities were found with Hebrew devices, for example, the use of alliteration and assonance, colourful metaphors, repetition (and redundancy), word-play, terseness, inclusio, chiasm, and parallelism (including 3-fold parallelism). The functions achieved by these devices in most cases were the same in both Hebrew and Zulu, for example the use of repetition to unify the poem, add rhythm, and help with memorability; the use of assonance and alliteration for aesthetic effect and as mnemonic devices; and the use of parallelism for emphasis, rhythm, memorability, and rhetorical effect. Some examples are from the Zulu translations that highlight the presence of the original Hebrew author are provided below.

\section{Use of Parallelism, Assonance, and Alliteration}

Psalm 93:3 uses three-fold parallelism for rhetorical effect, alliteration in 3a and $3 \mathrm{~b}$, and assonance in $3 \mathrm{~b}$ and $3 \mathrm{c}$ : 
402 Dickie, "Translation for and in Performance," OTE 31/2 (2018): 399-422

\begin{tabular}{|c|c|c|c|}
\hline $3 \mathrm{a}$ & $\begin{array}{l}\text { LORD } \\
\text { LOR! }\end{array}$ & $\begin{array}{l}\text { נִּרוֹ } \\
\text { the floods }\end{array}$ & 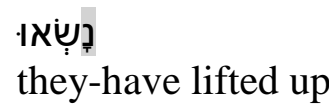 \\
\hline $3 b$ & $\begin{array}{l}\text { קiֹלָם ; } \\
\text { their-voice }\end{array}$ & $\begin{array}{l}\text { נִ נְרוֹת floods } \\
\text { the flo }\end{array}$ & $\begin{array}{l}\text { נָשְׁאו } \\
\text { they-have lifted up }\end{array}$ \\
\hline $3 c$ & $\begin{array}{l}\text { their-roaring } \\
\text { the }\end{array}$ & $\begin{array}{l}\text { נִ דְרוֹ } \\
\text { the floods }\end{array}$ & $\begin{array}{l}\text { "ש̣!" } \\
\text { they-lift up }\end{array}$ \\
\hline
\end{tabular}

The use of threefold-parallelism is also apparent in some Zulu praisepoems, for example the Izibongo of Senzangakhona: ${ }^{6}$

UMlunguzi wezingoje,

(Peerer over precipices)

Owalunguz' ingoje yomfowabo,

(Who peered over the precipice of his brother)

Owalunguz' ingoje kaZivalele.

(Who peered over the precipice of Zivalele.)

Thus the pattern seen in the Hebrew of Psalm 93 can be followed in Zulu too, retaining the presence of the voice of the "original author". The poem below ${ }^{7}$ shows this 3-fold parallelism, as well as assonance (e.g. the $a$ sound in the second line) and alliteration (e.g. the $i$ sound in the first line):

Imifula igcwele kakhulu,Nkosi,

(The rivers are very full, Lord,)

ulwandle nemifula kuzwakala ngomsindo,

(the ocean and rivers are heard by their noise,)

ngomsindo omkhulu ulwandle luyezwakala.

(through its very loud noise, the ocean is heard.)

Another example of the use of parallelism used for emphasis and literary beauty is found in the Hebrew of Ps 145:1-2.

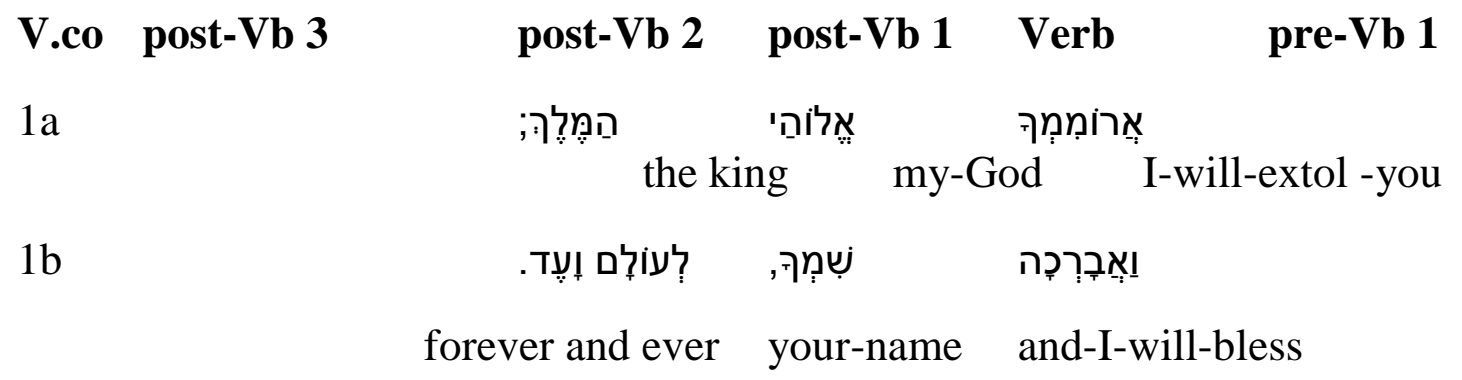

\footnotetext{
${ }^{6}$ Cope, Izibongo, 77, lines 42-44.

${ }^{7}$ Dickie, "Zulu Song”, Item 19 in Appendix $1 b$.
} 
Dickie, "Translation for and in Performance," OTE 31/2 (2018): 399-422 403

$2 \mathrm{a}$

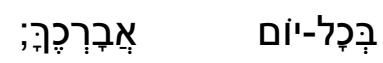

I-will-bless you in-all-days

$2 b$

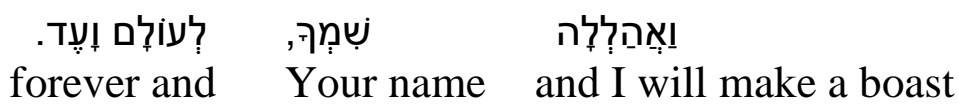

The Zulu translations tended to retain this parallelism, also using three different verbs (highlighted below) for literary effect, and to repeat the middle verb (1b, 2a), thereby assisting with memorisation:

E.g. ${ }^{8}$

1a. Ngizokukuphakamisa kakhulu, Simakade Nkosi,

(I will lift you up much, LORD King, )

1b. ngizolidumisa igama lakho phakade na phakade.

(I will praise your name forever and ever.)

2a. Zonke izinsuku ngizolidumisa.

(All the days I will praise-it)

2b. Ngizozigqaja ngegama lakho phakade na phakade

(I will boast about your name forever and ever.

\section{Use of Chiasm and Inclusio}

The Hebrew text in Ps 93 shows an inclusio structure in cola 1a and 5b. Chiastic structures are also apparent, for example in cola 1a-b and 1c:

1a

$1 b$

$1 \mathrm{c}$

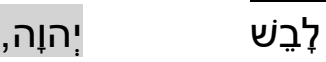

the-LORD He-is clothed

$5 b$

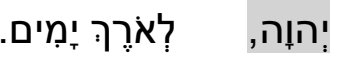

$$
\begin{aligned}
& \text { for-length- LORD } \\
& \text { of-days }
\end{aligned}
$$

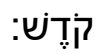$$
\text { נָאחוָה- }
$$

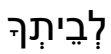

holiness

befitting

to-your-

house

The following translated poem ${ }^{9}$ also shows an inclusio (in the same cola as the Hebrew text) and chiasm (but in different cola, viz. 1a-b and 5b):

8 Dickie, "Zulu Song”, Item 20 in Appendix 1c.

9 Dickie, "Zulu Song”, Item 6 in Appendix 1b. 
404 Dickie, "Translation for and in Performance," OTE 31/2 (2018): 399-422

$\begin{array}{ll}\text { 1a. UJehova uyinkosi } & \text { (The LORD is King) } \\ \text { 1b. Ubukhosi bungobakhe } & \text { (The majesty is his) } \\ \text { 5b. ubungcwele bungobakho, Jehova } & \text { (holiness is yours, LORD) }{ }^{10}\end{array}$

Another example of Hebrew poetic devices that were retained in the Zulu translations is apparent in Ps 134. The Hebrew in vv.1-2 shows two chiastic patterns: ${ }^{11}$

\begin{tabular}{|c|c|c|c|c|c|}
\hline V.co & post-Vb 3 & post-Vb 2 & post-Vb 1 & Verb & pre-Vb \\
\hline \multirow[t]{2}{*}{ 1a } & יחוּוְה & 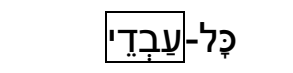 & אֶת-'יְחוָה & בדּרְּוּ & חִּנְּה \\
\hline & LORD & all-servants-of & DO- LORD & bless(2PP) & Behold \\
\hline \multirow[t]{3}{*}{$1 b$} & בַבְלִילוֹת & דְּבְבית-יְהוָה & הָעמדִדִים & & \\
\hline & at-night & in-house-of & the ones & & \\
\hline & & -the LORD & standing/servi & & \\
\hline \multirow[t]{2}{*}{$2 \mathrm{a}$} & & קָדָש & 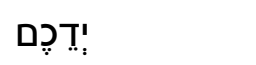 & שְׁאו-י & \\
\hline & & (to) holy & your-hands & Lift up(2PP) & \\
\hline \multirow[t]{2}{*}{$2 b$} & & & אֶת-יְהוָה & וּבְרְכוּו & \\
\hline & & & DO- LORD & and-bless(2PP) & \\
\hline
\end{tabular}

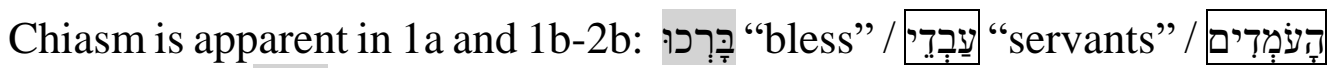

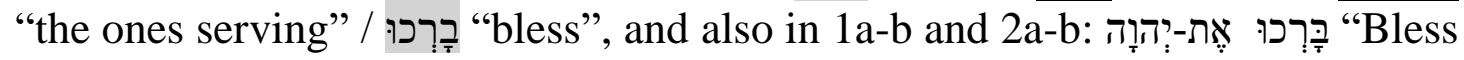

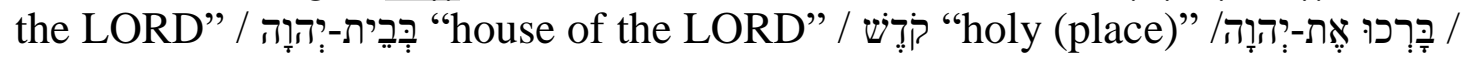
"Bless the LORD".

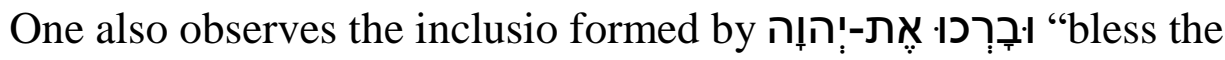
LORD" in cola $1 \mathrm{a}$ and $2 \mathrm{~b}$.

Zulu translations of these two verses show a similar use of the poetic features of chiasm and inclusio, with a similar purpose, viz. to provide rhythm and unite the two verses, signifying a point of departure at v.3, the key verse of

10 This translation omits the notion of 'house' from the Hebrew בִ (colon 5b). However, other translations did incorporate the semantic richness in the Hebrew term. See section 2.4.

11 The second pattern is noted by Walter Brueggemann and William H. Bellinger, Psalms (New York: Cambridge University Press, 2014), 560. 
Dickie, "Translation for and in Performance," OTE 31/2 (2018): 399-422 405

the psalm. ${ }^{12}$ Two examples below illustrate how Zulu poets introduced chiasm and inclusio into their translations:

Example 1: Zulu ${ }^{13}$ use of chiasm (1a-b and 1b-2b of Ps 134)

1a. Lalelani! Makadunyiswe uNkulunkulu,

(Listen! (May you) praise God,)

1b. zisebenzi zonke, nina enisebenz' ubusuku nemini.

(all you servants who work night and day.)

2a. Phakamiselani izandla zenu endlini engcwele,

(Lift your hands in the holy place,)

2b. nimnike uNkulunkulu udumo

([and] give God praise.)

Example 2: Zulu ${ }^{14}$ use of inclusio

1a. Lalelani! Mdumiseni uSimakade,

(Listen! Praise the LORD)

1b. nina nonke zinceku zikaSimakade

(all you servants of the LORD)

1b. enimkhonza ubusuku nemini. assonance

(who worship Him night and day.)

2a. Phakamiselani izandla zenu endaweni engcwele,

(Lift up your hands to the holy place,)

2b. nimdumise uSimakade.

([and] praise the LORD.)

\section{Use of Colourful Metaphors and Repetition thereof}

Psalm 93:3 in the Hebrew shows use of the metaphor of rising floods. The same imagery is used again in cola $4 \mathrm{a}$ and $4 \mathrm{~b}$, although the Hebrew does not repeat the same words from v.3. However, there is a repetition of "mighty" from $4 \mathrm{~b}$ to $4 \mathrm{c}$, providing a link from the threat in $4 \mathrm{~b}$ to the power of the LORD in $4 \mathrm{c}$ :

$3 a$

$3 b$

$$
\text { LORD }
$$

קוֹלָם";

their-voice

\section{נִּרוֹת} the floods

נִָּרוֹת

the floods
נָשְׁאו they-have lifted up

נָשְׁאו

they-have lifted up

12 Support for this notion of v.3 being the "peak" of the psalm comes from the following (X, 130): a significant shift of subject to YHWH (doing the blessing), an attributive phrase appositional to YHWH, a key term ('Zion'), a formula ('heaven and earth') and the use of a jussive (after four imperative verbs).

13 Dickie, "Zulu Song", Item 2 in Appendix 1a.

14 Dickie, "Zulu Song", Item 10 in Appendix 1a. 
406 Dickie, "Translation for and in Performance," OTE 31/2 (2018): 399-422

\begin{tabular}{|c|c|c|c|c|}
\hline $3 c$ & & their-roaring & $\begin{array}{c}\text { נָּרוֹ } \\
\text { the floods }\end{array}$ & $\begin{array}{l}\text { they-lift up } \\
\text { they }\end{array}$ \\
\hline $4 a$ & & & $\begin{array}{l}\text { many waters } \\
\text { maים רֵבְים-- }\end{array}$ & $\begin{array}{l}\text { מִקלוֹת, } \\
\text { Above-the thundering }\end{array}$ \\
\hline \multirow[t]{2}{*}{$4 \mathrm{~b}$} & & 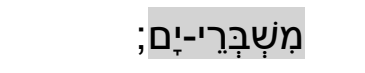 & אַדִירִים & \\
\hline & & breakers-of-sea & a mighty & (above-the thundering) \\
\hline $4 c$ & 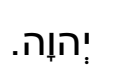 & בַּמָרוֹם & (אַדִיל & \\
\hline & LORD & on-high & mighty & (is) \\
\hline
\end{tabular}

The following translated poem ${ }^{15}$ uses different imagery in verses 3-4 to that of the source text. The Hebrew metaphor (that of powerful waves overwhelming the writer) has Ugaritic and Canaanite mythology as the background: Baal fights and defeats the chaos-enemy, Sea. ${ }^{16}$ For ancient Israel, the sea symbolized the unknown, the feared. By metonymy, it may also refer to the hostile nations who opposed Israel and thus YHWH. ${ }^{17}$ As the metaphor of turbulent waves was not meaningful to the Zulu youth, they were encouraged to find picture language that represented to them a significant threat or something that aroused fear. Many chose to use natural phenomena such as wind or electric storms, but for others, the lion represented to them "the most feared". The poet below used two pictures, that of a lion and wind, which convey the same feeling of fear as the Hebrew. Moreover, as in the source text, the images used in v. 3 are repeated in v.4, thereby emphasising the fact that the LORD is more powerful than the threats, which is the main point of the Hebrew text. Thus, although the metaphor has changed, the message remained the same.

3a Nakuba isitha sibhodla okwebhubesi,

(Even tho' the enemy roars like a lion,)

3b Nakuba izivunguvungu zisihlasela ngamandla,

(Even tho' strong winds attack us with force,)

3c Nakuba umoya uvunguza ngamandla,

(Even tho' the wind is blowing strongly with power,)

4a inamandla Inkosi ngaphezu kwebhubesi,

(the Lord is more powerful than the lion,)

$4 \mathrm{~b}$ inamandla Inkosi ngaphezu kwezivunguvungu,

(the Lord is more powerful than the strong wind,)

15 Dickie, "Zulu Song", Item 12 in Appendix 1b.

16 F-L. Hossfeld and E. Zenger, Psalms, vol. 2 (Minneapolis: Fortress Press, 2005), 449. It links back also to the threatening waters before order was first instituted in the Creation, with the separating of the land from the sea (Gen 1:6).

${ }^{17}$ Cf. Isa. 57:20; Jer. 49:23. 
Dickie, "Translation for and in Performance," OTE 31/2 (2018): 399-422

4c inamandla Inkosi ngaphezu kwezivungu-vungu ezivunguza ngamandla. (the Lord is more powerful than the strong wind that is blowing with power.)

\section{Careful use of vocabulary}

The Zulu culture is in many ways closer to that of the Hebrew than Western culture, and consequently the notions contained in Zulu words often more closely approximate the Hebrew idea than the English. For example, the term "house(hold)" in Ps 134:1b does not just refer to the building ("house") but also the people ("household) and the Zulu word indlu captures this idea.

Example ${ }^{18}$

Indlu yakho ingcwele njalo-njalo

(Your house(hold) is a place of holiness forever and ever)

Another example is the translation of אִ אִ in Ps 145:2b. BDB indicates that a significant part of the meaning of this verb is the notion of boasting. Although no English version consulted implies that idea, one of the Zulu poets used the verb ngizozigqaja ("I will boast about"), thereby reflecting the Hebrew author's intent very well. Thus, the Zulu translations can more accurately reveal the voice of the original writer through careful choice of vocabulary.

\section{$5 \quad$ Ideational Rhythm}

In my doctoral research, ${ }^{19}$ I concluded that there are two main kinds of rhythm, viz. literary rhythm and musical rhythm. The former can be further analysed into four components:

- Sound rhythm (arising from the choice of particular words making a pattern of similar sounds, as in assonance, alliteration, and word play)

- Ideational rhythm (arising from a pattern of images followed by a break in the established pattern)

- Lineal rhythm (arising from the formulation of the poetic line). This includes "terseness of style" which contributes to the lineal rhythm through its abbreviated use of language.

- Structural symmetry (arising from special symmetrical syntactical patterns, such as parallelism, chiasm, inclusio, and acrostic).

18 Dickie, "Zulu Song", Item 12 in Appendix $1 \mathrm{~b}$.

19 See Dickie, "Zulu Song", 76. At that stage, I referred to sound rhythm, poetic rhythm, and musical rhythm, but this paper distinguishes three elements of "poetic rhythm". The four components linked to literary features together comprise "literary rhythm". 
Dickie, "Translation for and in Performance," OTE 31/2 (2018): 399-422

2d. nibusise Inkosi.

3a. Inkosi mayinbusise entabeni yase Siyoni,

3b. Makanibusise owenzile izulu nomhlaba. bless the Lord.

May the Lord be blessing on the mountain of Zion, May he bless you, he who created heaven and earth.

\section{Repetition of Key Terms}

Ps 134 uses the Hebrew verb בְּר ('bless') to refer to both man blessing God and God blessing man. The Zulu poets similarly chose (from the repertoire of available verbs within the relevant domain) the particular verb which also includes the action in both directions (as in the Hebrew). The Zulu verb (like the Hebrew verb) has different meanings in the two directions: 'praise' when from man to God, and 'show favour' when from God to man. However, what is interesting for this paper is that the key term ('bless') was consistently translated by -busisa- in the important contexts. In the poem below, ${ }^{23}$ two verbs were used for "bless" (-busisa- and -dumisa-, in 2c). It is likely that the other term was used in colon $2 \mathrm{~d}$ (which is parallel to $2 \mathrm{c}$ ) to give some variety, the parallel lines providing good rhythm, typical of Zulu poetry.

\section{1a. Lalelani!! Busisani Inkosi}

1b. nibe izikhonzi zeNkosi

1c. ezi-hlala ethempeli le Nkosi

1d. ebusuku nasemini.

2a. Phakamisani izandla

2b. endaweni engcwele

2c. niyidumise Inkosi,

2d. nibusise Inkosi.

3a. Inkosi mayinbusise entabeni yase Siyoni,

3b. Mayinibusise owenzile izulu nomhlaba. created
Listen, bless the Lord,

all servants of the Lord

who sit in the temple of the Lord

night and day.

Lift up hands

to the holy place

(and) bless the Lord

(and) bless the Lord.

May the LORD bless you on the mountain from Zion

May he bless you, (he) who heaven and earth.

23 Dickie, "Zulu Song", Item 21 in Appendix 1 a. 
410 Dickie, "Translation for and in Performance," OTE 31/2 (2018): 399-422

\section{PRESENCE OF THE TRANSLATOR}

A translator of poetry must be a poet, and although s/he must "dance in chains", ${ }^{24}$ the focus is less on strict adherence to the form of the original text and more on features of artistry and aurality. There are therefore many innovations introduced by the Zulu poets to the original Hebrew texts. A few are highlighted below.

\section{Different Interpretations given to Hebrew Words}

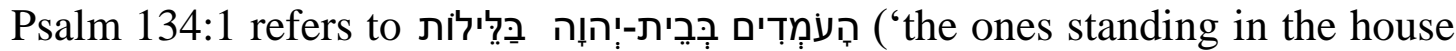
of the LORD at night'). Two poets independently chose alternative interpretations for 'standing' and 'night'. The one ${ }^{25}$ used the expression nibambelelek' uSimakade kunzima ('you who hold on intensely to the LORD in difficulties') and the other opted for the same interpretations of the two Hebrew

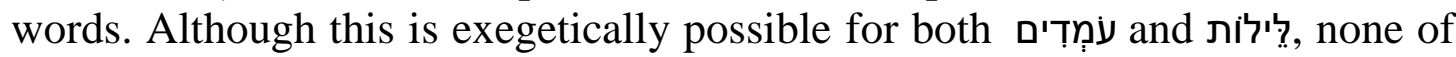
the published translations referenced used this interpretation. Although it is not the probable interpretation in the cultic context, it is of interest as it reflects a theoretical principle found in Reception Theory: ${ }^{26}$ the 'gaps' (in meaning in the source text) provide hermeneutic opportunities for the hearers to apply the text in a meaningful way to their personal situations. The two poets who took this interpretation were both experiencing a great deal of difficulty in their personal lives, and it is possible that the more symbolical interpretation was particularly meaningful to them.

\section{Insight from Metaphors}

One of the poets of Ps $93^{27}$ introduced the metaphor of a "lion" into the inclusio frame (cola 1c-d) where the Hebrew used the image of being "girded with strength'. Then the poet re-used the same image with a twist (i.e. a simile instead of a metaphor) in colon 3c. This suggests that the enemy may try to appear strong, but the real lion (or strong one) is the LORD. This seems to be a powerful insight. To emphasise this point, the poet used two different words for 'lion' the first is linked with royalty and the Zulu chief, while the second is the common word for 'lion':

24 Barnstone quotes the way the Chinese describe the method of the great Tang poets, viz. working imaginatively while being bound by strictures (Willis Barnstone, The Poetics of Translation: History, Theory, Practice [New York: Yale Univ. Press, 1993], 270).

25 Dickie, "Zulu Song", Item 17 in Appendix 1a.

26 See Paul A. Soukup, "Understanding audience understanding" in From one medium to another: communicating the Bible through multimedia (eds. Paul A. Soukup and Robert Hodgson; Kansas City: Sheed \& Ward, 1997), 103-107.

27 Dickie, "Zulu Song" Item 6 in Appendix 1b. 
1c. Jehova, uyingonyama ${ }^{28}$

(LORD, you are the royal lion)

3c. sihlasela kuhle kwebhubesi,

([the enemy] attacks like a [common] lion,)

It is clear that a number of valuable revelations can come to light as people bring their own contexts and creativity into their understandings of biblical texts. Since the participants in this study made their own translations, another layer of richness was added to the truth of the biblical message.

\section{Use of a Different Formula}

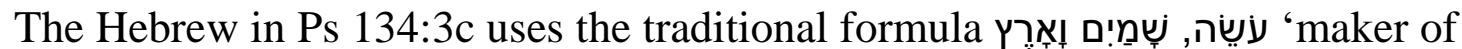
heaven and earth'. One poet ${ }^{29}$ replaced this with two expressions in parallel, carrying with them the same broad reference metonymically to the Creator of all. Moreover, in his new formula, the poet introduced parallelism, thereby adding to the rhythm and beauty of the poem, as well as giving extra focus to $3 \mathrm{a}-\mathrm{b}$ (to which $3 \mathrm{c}$ and $3 \mathrm{~d}$ are in apposition). The use of a demonstrative $l o$ (in $3 \mathrm{c}$ ) also gives prominence to the agent / topic (in 3a).

3a. Engathi Inkosi yamakhosi

(May the Lord of lords,)

inganibusisa eyaseSiyoni.

(the One from Zion, may he bless you.)

3b. Engathi anganibusisa,

(May he bless you,)

3c. lo owahlukanisa ubumnyama nokukhanya,

(this one who separates darkness and light,)

3d. owahlukanisa amanzi nolwandle.

(he who separates water and sea.)

\section{$4 \quad$ Step-down Parallelism}

Parallelism in Hebrew text often shows a step-up (additive) nature. However, several examples in Zulu show step-down parallelism. For example, from $2 b$ to $2 \mathrm{c}$, from $3 \mathrm{a}$ to $3 \mathrm{~b}$, and from $3 \mathrm{c}$ to $3 \mathrm{~d}$ in the following poem: ${ }^{30}$

2b. ninike Inkosi yamakhosi udumo,

(Give $^{31}$ the Lord of lords praise,)

2c. nimubusise lo aphakeme.

(bless this, the high one.)

28 Uyingonyama is used as a praise name for the Zulu chief, referring to a special lion, one that is majestic.

29 Dickie, "Zulu Song”, Item 23 in Appendix $1 \mathrm{~b}$.

30 Dickie, "Zulu Song", Item 23 in Appendix 1b.

31 Although ninike (2b) and nimubusise (2c) are subjunctives, they carry imperative force as they follow an imperative in $2 \mathrm{a}$ (not shown). 
412 Dickie, "Translation for and in Performance," OTE 31/2 (2018): 399-422

3a. Engathi Inkosi yamakhosi inganibusisa eyaseSiyoni,

(May the Lord of lords, the one from Zion, may he bless you,)

3b. engathi anganibusisa

(may he bless you,)

3c. lo owahlukanisa ubumnyama nokukhanya

(this one who separates darkness and light,)

3d. owahlukanisa amanzi nolwandle.

(he who separates water and sea.)

Another example $\mathrm{e}^{32}$ of step-down parallelism is seen in the poem below, from 1e to 1f:

1d. Impela, umhlaba uqinile kakhulu,

(Really, the earth is very firm,)

1e. uqinile ungeguqulwe yilutho,

(it is firm, nothing can shake it,)

1f. ungeguqulwe yilutho.

(nothing can shake it.)

As Nida observed in 2003:33 "Some of the Zulu poets are extremely skilled in producing praise poems ..." The presence of the Zulu translator is very apparent in most of the Zulu compositions, but this not only makes the text sound like a Zulu poem, but often yields exegetical insights too. ${ }^{34}$

\section{$5 \quad$ Adjustments to Maintain the Lineal Rhythm}

The rhythm of the poetic line is very important to a Zulu poet, and thus some words may need to be repeated or shortened to maintain a regular rhythm. In Ps 134:2, the Hebrew shows three words in colon $2 \mathrm{a}$ and two words in colon $2 \mathrm{~b}$.

$2 \mathrm{a}$

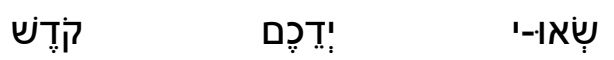

(to) holy your-hands Lift up(2PP)

$2 b$

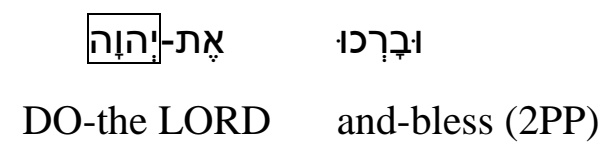

However, some Zulu poets added words to maintain a regular rhythm over this verse (not a key verse, and thus not requiring a change of rhythm for emphasis). For example: ${ }^{35}$

2a. Izandla - izandla zonke ziphakame

(Hands - hands all let them lift up)

32 Dickie, "Zulu Song”, Item 19 in Appendix 1 b.

33 Eugene A. Nida, Fascinated by Languages (Amsterdam: John Benjamins, 2003), 82.

34 See section 2.4.

35 Dickie, "Zulu Song”, Item 3 in Appendix 1a. 
2b. zidlule ikhanda kophakeme (above the head to the one above)

2c. nimdumise uJehova

([and] praise the LORD)

One important thing in this example is that the poet has interpreted "the holy" as "the one above" (implying 'in the holy place') and has added the notion of "lifting above" to give emphasis. Moreover, he has used two synonyms for "above" in $2 b$, thereby giving literary richness to the poem. He has also introduced assonance with the use of ikhanda "head" (not in the Hebrew) to sound beautiful and memorable along with izandla "hands" in colon 2a. The first line (2a) also shows deliberate alliteration. This assonance and alliteration were not present in the Hebrew text.

\section{Change of Lineal Rhythm to give Focus to Key Verses}

The Hebrew of Ps 134 shows a regular formulation of the poetic line across the psalm, with either 3 or 2 stressed syllables in each strophe.

\begin{tabular}{|c|c|c|c|c|c|c|}
\hline V.co & post-Vb 3 & post-Vb 2 & post-Vb 1 & Verb & pre-Vb 1 & \# stress \\
\hline \multirow[t]{2}{*}{$1 \mathrm{a}$} & 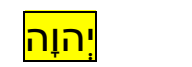 & כָּל-עַבְדַדי & אֶת-יְהוָה & בָּרְכָוֹ & הִּנֶה & \\
\hline & the LORD & all-servants-of & \multicolumn{2}{|c|}{ DO-the LORDbless(2PP) } & Behold & $3+2$ \\
\hline \multirow[t]{2}{*}{$1 b$} & 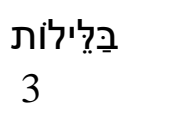 & 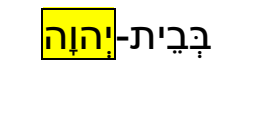 & \multicolumn{4}{|l|}{ רָעׁמִדִים } \\
\hline & at-night & $\begin{array}{l}\text { in-house-of } \\
\text {-the LORD }\end{array}$ & \multicolumn{4}{|l|}{$\begin{array}{l}\text { the ones } \\
\text { standing }\end{array}$} \\
\hline \multirow[t]{2}{*}{$2 \mathrm{a}$} & & קָדֶש & 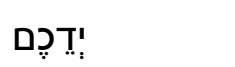 & \multicolumn{2}{|l|}{ שְׁאו-י } & 3 \\
\hline & & (to) holy & your-hands & \multicolumn{3}{|l|}{ Lift up(2PP) } \\
\hline \multirow[t]{2}{*}{$2 b$} & & & אֶת-:יוּוָה & \multicolumn{2}{|l|}{ וּבְרְכוּ. } & 2 \\
\hline & & & \multicolumn{3}{|c|}{ DO-the LORD } & \\
\hline \multirow[t]{2}{*}{$3 a$} & & מִצִּיוֹן & 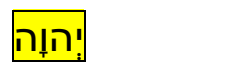 & \multicolumn{2}{|l|}{ 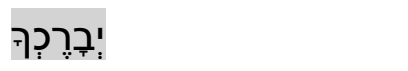 } & 3 \\
\hline & & from-Zion & the LORD & \multicolumn{3}{|c|}{ May-he-bless-you(sg) } \\
\hline \multirow[t]{2}{*}{$3 b$} & וָאָרֶץ & שַׁמִַים & עושׁה & & & 3 \\
\hline & and-earth & heavens & \multicolumn{4}{|c|}{ the one-making } \\
\hline
\end{tabular}


414 Dickie, “Translation for and in Performance," OTE 31/2 (2018): 399-422

However, some of the Zulu poets chose to change the rhythm pattern in v.3, to highlight this verse as the key verse in the poem. The example below ${ }^{36}$ shows a regular rhythm in verses 1 and 2 of three stressed syllables per poetic line (marked in bold). This changes in v.3 to four stressed syllables (marked in bold). To achieve these extended lines in cola $3 \mathrm{a}$ and $3 \mathrm{~b}$, the poet made two ideas explicit, viz. that Zion is a mountain, and the repetition of the verb in $3 b$ (from 3a).

\author{
1a. Lalelani!! Busisani Inkosi \\ (Listen, bless the Lord) \\ 1b. nibe izikhonzi zeNkosi \\ (all servants of the Lord) \\ 1c. ezi-hlala ethempeli le Nkosi \\ (who sit in the temple of the Lord) \\ 1d. ebusuku nasemini. \\ (night and day.) \\ 2a. Phakamisani izandla \\ (Lift up hands) \\ 2b. endaweni engcwele \\ (to the holy place,) \\ 2c. niyidumise Inkosi, \\ ([and] bless the Lord) \\ 2d. nibusise Inkosi. \\ ([and] bless the Lord.) \\ 3a. Inkosi mayinbusise entabeni yase Siyoni \\ (May the LORD bless you on the mountain from Zion) \\ 3b. Mayinibusise owenzile izulu nomhlaba. \\ (May he bless you, (he) who created heaven and earth.)
}

\title{
7 Use of Tail-Head Linkage for Memorability and Rhythmic Beauty
}

As Zulu poetry is always performed and heard, it needs to include mnemonic devices to assist the hearer to remember the key ideas. A common device used for this purpose is tail-head linkage, where the last word in one line is repeated as the first word in the next line.

Example $^{37}$

3a. Makanibusise uSimakade

(May the LORD bless you)

3b. uSimakade owenze umhlaba nezulu.

(the LORD who made earth and heaven.)

Here we see the translator's voice, adding something not seen in the Hebrew text but necessary for Zulu performance.

36 Dickie, "Zulu Song", Item 21 in Appendix 1a.
37 Dickie, "Zulu Song", Item 17 in Appendix 1a. 
Dickie, "Translation for and in Performance," OTE 31/2 (2018): 399-422

\section{Ideational Rhythm for Memorability and Performability (e.g. as rap)}

Zulu poetry utilises many oral devices to help the performer and hearer remember the text easily. In the translation of Ps 145:4-7 below, ${ }^{38}$ the poet used the 2PS possessive at the end of every line (except for one), facilitating memorability and performability.

4a. Isizukulwane siyakudumisa nezenzo zakho,

(Generations will praise your acts,)

4b. abanye bakhulume ngamandla ezenzo zakho.

(others speak about power of your deeds.)

5a. Ngiyakugxila ekuphakamiseni ubukhosi,

(I will focus on lifting up your majesty,)

5 b. nenkazimulo yakho kanye nezimangaliso zezenzo zakho.

(and your glory and wonderful deeds.)

6a. Bayakufakaza ngamandla ezimangaliso zezenzo zakho;

(They will proclaim about the marvellous power of your deeds;)

6b. Ngiyakumemezela ubukhulu bakho.

(I will declare your greatness.)

7a. Bayokukhuluma ngadumo olukhu lomusa wakho

(They will talk about the great fame of your mercy,)

7b. bacule ngobulungiswa bakho.

([and] sing about your justice.)

Thus the Zulu poets' commitment to use their own indigenous features of oral art resulted in biblical texts that are perceived as being genuine Zulu poetry, rather than simply translations.

\section{PRESENCE OF THE PERFORMER}

Several features of the performance served to highlight different parts of the translated (Zulu) text. The pace of delivery (of both the rhythm and the enunciation) as well as the combination of various media (song, rap, spoken word) served to highlight key themes and maintain the interest of the audience.

\section{Pace of Delivery}

In some cases, features of the performance served to highlight a particular verse as being in focus. In a sung version of his translation of Ps 134, the singer significantly increased the beat of the music before colon $3 \mathrm{a}$. He also slowed down the pace as he sang the final words in colon $3 \mathrm{~b}$. These two devices gave prominence to verse 3 in the psalm, which is the key verse. The performance greatly added to the communicative effectiveness of the poem.

38 Dickie, "Zulu Song”, Item 8 in Appendix 1c. 


\section{Use of Song and Spoken Word}

A performance of Ps $93^{39}$ included both song and spoken word, with two different performers presenting their own translations in a complementary way. The use of different media keeps the attention of the audience.

Another performance of Psalm 93 brought together three different translations, ${ }^{40}$ with the three men interleaving their compositions in a dramatic reading. They tried to use body language to communicate something of the message, as well as a fast pace to capture the rhetorical force, as is typical in Zulu praise poetry. The final cola slows down to emphasise the LORD's victory "always" (with the slow choral enunciation of njalo-njalo "always").

\section{Selection of Cola and Adjustment of Words}

Often, the performers adjusted the word order to better fit the musical rhythm. This is important since Zulu is a tonal language, and the musical melody and the tonal melody must be synchronised. Also, the stress of the word needs to match the beat (musical rhythm). Furthermore, the songs usually selected a number of verses or cola, rather than trying to include the entire translated poem. For example, the song from the translation below includes the items in grey. The word in bold in the translation was replaced with a synonym in the song. Only certain colas were included in the song (none from verse 3), and some elements of the translation were adjusted, e.g. 'day and night' in the translation became 'forever and ever'.

One notion is included in the song (in the second last line) which has no equivalent in the biblical psalm nor in the Zulu translation thereof.

Translation $^{41}$
Zulu
1a. Bukani. Dumisani uJehova,
1b. nina nonke zinceku,
1c. zikhonzi zonke zika Jehova,
1d. ezimile endlini kaJehova
1d. zikhonza imini nobusuku.
2a. Izandla-izandla zonke ziphakame
2b. zidlule ikhanda kophakeme,
2c. nimdumise uJehova.
3a. Anibusise uJehova waseSiyoni,
3b. yena yedwa yilo lelo-dwala
3c. owadala izulu nomhlaba

\author{
English Translation \\ Look! Praise the LORD, \\ all you servants, \\ all you worshippers of the LORD, \\ who stand in the house of the LORD \\ worshipping day and night. \\ Hands, hands - lift them all high \\ above the head to the high one, \\ praise the LORD. \\ May He bless you, the LORD of Zion. \\ he alone, that big flat rock, \\ the one who created heaven and earth.
}

39 Dickie, "Zulu Song", Items 28 and 29 in Appendix 1b.

40 Dickie, "Zulu Song", Items 27, 30, and 31 in Appendix 1b.

41 Dickie, "Zulu Song”, Item 3 in Appendix 1a. 
Song

Zulu

1a, c Bukani badumisi!

1a. Dumisani uJehova,

1b. nina nonke zinceku

1d-e. enimile phakade kakade

2b. Uphakeme ungcwele

2c. Nimdumise, badumisi owaSebawoti uJehova

1a. Nimdumise, nimdumise! (x2)

\section{English Translation}

Look, praisers!

Praise the LORD, all you servants who are standing forever and ever. He is high and holy (Let you) praise him, praisers, the LORD who is on High (Let you) praise him! (x2)

This example shows the loss of some content in the song. However, this was not always the case; one gifted musician was able to sing the complete psalm..$^{42}$ Obviously, with practice, the transposing of a poem to a song would improve.

In another performance (one of Ps 145 ) ${ }^{43}$ the singer conflated the text of the first two lines of the translation and used that as a chorus, repeated several times. The translation began with the lines:

1a. Ngizokuphakamisa wena Jehova wami Nkosi,

(I will lift you up, you LORD, my king,)

1b. ngizolidumisa igama lakho njalo.

(I will praise your name forever.)

In the performance, the conflation of these two lines became:

Ngizophakamisa igama lakho

(I will lift up your name)

In another performance of Ps 145:1-2, ${ }^{44}$ the singer included all the words, with some repetition of the word njalo ("always/continually") and the addition of a "nonsense syllable" (at the end of colon $2 b$ ) to fit the melody and rhythm. Apart from these small adjustments to the translated text, the song followed the translation. It must be said that this performer, a young woman, is extremely musically talented, and converted the poem into a song within thirty minutes. The melody varied, soaring to high notes on the repetition of colon 1a. The words were easy to remember, and the singer had the audience clicking along in unison.

The text is as follows:

1a. Ngiyakuphakamisa ubukhulu akho,

(I will lift up your greatness,)

42 See for example, Dickie, "Zulu Song", Item 22 in Appendix 1a and Item 32 in Appendix 1c.

43 Dickie, "Zulu Song", Item 8 in Appendix 1c.

44 Dickie, "Zulu Song", Item 32 in Appendix 1c. 
418 Dickie, "Translation for and in Performance," OTE 31/2 (2018): 399-422

Nkulunkulu wami oyinkosi,

(My God who is the king,)

1b. Ngiyakukubonga njalo-njalo.

(I will thank you continually.)

2a. Ngiyakukubonga onke amalanga,

(I will thank you all the days,)

2b. ngikutuse njalo-njalo.

(I praise you continually [nonsense syllable]).

Thus, the Zulu performer of a biblical text (as probably all performers) feels the liberty to adjust the given text, if necessary, to the needs of the performance. Generally, the meaning was not changed in any significant way, and usually no extraneous ideas were included. One example ${ }^{45}$ where an idea was included in the song that was not in the translation is given below. The song is based on verses 1, 3, and 4 of Ps 145 . The performance text is:

Chorus

3a. uNkulunkulu wami akahluleki,

My God never fails

3b. uNkulunkulu wami sizodumisa,

1c. uNkulunkulu (5x) Uphakeme uphakeme

My God we will praise

God, He is high

Rapper 1:

1a Phakamisa udumo lwakho,

1b. Lonke lungo lwakho.

3a. Zenzo zonke zona ezinamandla

zona zinge zakho.

3b. Wena ukwenza konke ngamandla akho,

3c. wena uyasisiza endleleni,

wena uhamba nathi.

Sizodumisa

Lift your praise,

all is yours

All your deeds are

powerful,

they are yours.

You make all with your

power,

you are helping us on

our path,

you go with us.

We will praise

Chorus (sung) - as above, culminating with "Yeeh!!"

(Rapper 2)

Zulu

1a Phakamisa udumo lwakho,

1b. lonke lungo lwakho.

4a. Zukulwane, zukulwane,

4b. sona singesakho,

\section{English Translation}

Lift your praise, all is yours.

Generation, generation,

it is yours,

45 Dickie, "Zulu Song”, Song 52 in Appendix 1c. 
Dickie, "Translation for and in Performance," OTE 31/2 (2018): 399-422

4c. thina sonke umasihlangane,

4d. siphakamisa uNkulunkulu. we all together, we lift God.

In this performance, it is clear that the order of content from the three biblical verses has been changed (verse numbers indicated on the left of each line). However, it is only colon 3c (in grey above) which seems to contain content that is not in Ps 145, although it can be said to reflect biblical truth.

\section{E PRESENCE OF THE AUDIENCE}

The translated items were performed first before peers, and then before an invited audience of family and friends or the church congregation at a Sunday service. The response, especially in the larger group of a church congregation, was very evident, through clapping, ululating, and the taking of videos. Before the smaller audiences of peers, there was snapping of fingers and joining in with the humming of the performers. The more relaxed environment allowed for greater freedom and participation by the audience.

Interviews with audience members revealed their sense of inclusion in the performances. For example, when asked "What did you like best about the songs?", the response was "They were just songs that you can sing along with."46 The meaning of the texts was also considered to be accessible. One audience member noted: "[Most people will enjoy singing the songs] because the translation used is much easier to understand than the original translation we have." 47 The performances also were clearly memorable for many audience members. Comments such as the following revealed their metonymic capacity:

- "With the message they did using drums, I can even recall the scripture they used... It is not easy to forget the song." 48

- "I like many ways of preaching, which involve acting, and it helps people to remember what was said and done." 49

- "I think that Zulu people will like to create songs like these because it is ... a way to know the Bible. When we sing it, we remember the verses $\ldots . "{ }^{\prime \prime} 0$

Others indicated that the songs appealed to them because of their aesthetic power, either through the rhythm or the words. For example, one audience member observed: "I think people enjoyed [it]... because the song's words were

46 Dickie, "Zulu Song”, Interview 9 in Appendix 2c.

47 Dickie, "Zulu Song", Interview 5 in Appendix 2c.

48 Dickie, "Zulu Song", Interview 1 in Appendix 2c.

49 Dickie, "Zulu Song", Interview 3 in Appendix 2c.

50 Dickie, "Zulu Song”, Interview 9 in Appendix 2c. 
catchy, because this song is created in a way that can attract teenagers. And there was also a beat; beats are always catchy, that's why I like it."51

In the church context, the performances preceded the preaching, and the preacher later commented: "Before I preached, they gave me power, because they started first and gave a strong message." 52 From his perspective, the performance changed the "spiritual atmosphere" and made his work easier. Certainly, it was noticeable that most people became more alert with the start of the performances. And the performances were considered by the audience to be within the bounds of acceptability of "biblical text". As one noted, "[People will enjoy singing the songs] because of the message and it still is part of the scripture, not something we came up with."53

With the audience engaged and interested in the performances, as was clearly the case, the translation is more likely to become "something talked about and shared with friends". ${ }^{54}$ It was noted how all the young people in the audience jumped up once the performance began, and made video recordings on their phones of their peers performing. No doubt these performances would be shared with many others, and be a talking point.

Further work needs to be done in this area where the original (Hebrew) text are further transformed in performance. Zulu oral art over past centuries shows that the audience often interacts even vocally with the performer(s), thereby changing the direction of the movement of the text. It is expected that after several hearings of a text, the audience might become familiar with the theme and rhythm and add their own verses. However, it can be said from even the work done thus far, that lack of response from the audience will shut down the performer(s). Zulu audiences are attentive to indicate their enjoyment or otherwise, and the snapping of fingers to praise a clever or beautiful line is common in the performance of Zulu poetry. Conversely, the lack of response is a clear sign to the performer that his/her poem is not being received well.

\section{F CONCLUSION}

In the oral performance in Zulu of some biblical praise-psalms, four "presences" are evident. As the source text is biblical, it was expected that the voice of the "original author" would be apparent, although being poetry, one would not expect the Zulu translations to follow the form of the Hebrew poetry. The fact that they did, in some cases, is the result of both languages sharing certain poetic

51 Dickie, "Zulu Song", Interview 9 in Appendix 2c.

52 Dickie, "Zulu Song", Interview 3 in Appendix 2c.

53 Dickie, "Zulu Song”, Interview 6 in Appendix 2c.

54 Paul A. Soukup, "Understanding audience understanding" in From one medium to another: communicating the Bible through multimedia (ed. Paul A. Soukup and Robert Hodgson; Kansas City: Sheed \& Ward, 1997), 106. 
devices (such as chiasm, parallelism, assonance, and others) in their poetry. The Zulu poets showed an ability to maintain the literary and rhetorical power of the "original author" while presenting the message in a Zulu way, using rhythm and the typical style of Zulu praise poetry. Their voices were very apparent in the translations, using colourful images that speak to their situations, interpreting Hebrew words within their contemporary contexts, and adjusting the syntax to represent Zulu thought. It is hoped that translators of biblical poetry would explore ways to incorporate all the literary beauty and rhetorical power of the source text, and this study indicates that the inclusion of indigenous poets in the translation process and the application of the literary-rhetorical approach, can significantly help in this direction.

Moreover, when the poets then performed their items, they made further adaptations to fit the performance event. This included adjusting the word-order or choice of words, repeating words to fill the rhythm, selecting portions of the biblical text to have prominence, and so on. The audience also became involved in the performances, participating verbally and non-verbally, and connecting with the text in a meaningful way. Thus this study has also shown that insights from performance criticism should be borne in mind by the translator of biblical poetry. Some of the meanings of the texts can be transmitted using performance features rather than by being limited to words on a page. Also, presenting a biblical psalm through oral performance is far more engaging and memorable than using the traditional medium, and it is hoped that more communicators of the biblical message will experiment with the dynamics of performance, in light of the many benefits that it offers.

Careful translation can facilitate the voice of the original author to sing in the performed text, along with the dance movements of the translator, the innovations of the performer, and the responsiveness of the audience. All four "presences" contribute to the entire experience, and the translator of biblical poetry has all four of these voices available to him/her, to produce a new oral poem with all the lyrical beauty and dynamic persuasive power of the original text.

\section{BIBLIOGRAPHY}

Barnstone, Willis. The Poetics of Translation: History, Theory, Practice. New York: Yale Univ. Press, 1993.

Brueggemann, W. and Bellinger, W.H. Psalms. New York: Cambridge University Press, 2014.

Cope, A. Trevor. Izibongo Zulu Praise Poems. London: Oxford University Press, 1968.

Dickie, June F. "Zulu Song, Oral Art, Performing the Psalms to Stir the Heart." Ph.D thesis, University of Kwa-Zulu Natal, 2017.

Foley, John M. The singer of tales in performance. Bloomington: Indiana University Press, 1995. 
422 Dickie, "Translation for and in Performance," OTE 31/2 (2018): 399-422

Hossfeld, F-L. and Zenger, E. Psalms, volume 2. Minneapolis: Fortress Press, 2005.

Nida, Eugene A. Fascinated by Languages. Amsterdam: John Benjamins, 2003. https://doi.org/10.1075/z.119

Soukup, Paul A. "Understanding audience understanding." Pages 91-107 in From one medium to another: communicating the Bible through multimedia. Edited by Paul A. Soukup and Robert Hodgson, Kansas City: Sheed \& Ward, 1997.

Wendland, Ernst R. LiFE-Style Translating. Dallas: SIL, 2006.

June Frances Dickie. University of KwaZulu-Natal. E-mail:

junedickie@gmail.com. ORCID: https://orcid.org/0000-0002-5226-5874. 